\title{
MEMILIH DAN DIPILIH, HAK POLITIK PENYANDANG DISABILITAS DALAM KONTESTASI PEMILIHAN UMUM: STUDI DAERAH ISTIMEWA YOGYAKARTA
}

(To Vote and to be Voted, The Political Rights of People with Disabilities in The Contestation of General Election: The Study in Special Region of Yogyakarta)

\author{
Hilmi Ardani Nasution; Marwandianto \\ Badan Penelitian dan Pengembangan Hukum dan Hak Asasi Manusia \\ Jl. HR Rasuna Said Kavling 4-5 Kuningan Jakarta Selatan 12940 \\ hilmikumham@gmail.com; marwandianto6@gmail.com
}

Tulisan Diterima: 25-06-2019; Direvisi: 02-10-2019; Disetujui Diterbitkan: 1-11-2019

DOI: http://dx.doi.org/10.30641/ham.2019.10.161-178

\begin{abstract}
One of the rights that must be fulfilled by the government is the rights to vote and to be voted as the implementation of ratification of the International Covenant on Civil and Political Rights. The role of government in political rights in general is passive, but to fulfill political rights for disability groups is a special matter. This paper aims to give an overview and a critical analysis about the implementation of the political rights of disability groups, and to get a clearer description regarding the obstacles in fulfilling their political rights. This research is a qualitative research by collecting primary data from related stakeholders in Yogyakarta through in-depth interviews to find out more deeply about the fulfillment and obstacles to the fulfillment of political rights of disability groups. In this paper, it is revealed that there are potential regulations that apply in Indonesia to eliminate the political rights of disability groups, but also found that in the implementation of technical elections there are also obstacles that make disability groups unable to fulfill their political rights in the election. Therefore, a comprehensive step is needed by the government to guarantee the political rights of disability groups.
\end{abstract}

Keywords : human rights; disability; political rights; election.

\begin{abstract}
ABSTRAK
Memilih dan dipilih merupakan hak dasar bagi setiap orang yang harus dipenuhi oleh pemerintah sebagai pelaksanaan ratifikasi dari Kovenan Internasional Hak Sipil dan Politik. Peran pemerintah dalam hak politik secara umum bersifat pasif, namun untuk pemenuhan hak politik bagi kelompok disabilitas adalah perihal yang khusus. Tulisan ini bertujuan untuk memberikan gambaran terhadap pelaksanaan hak politik kelompok disabilitas, dan menganalisis hambatan-hambatan dalam pemenuhan hak politik penyandang disabilitas. Penelitian ini merupakan penelitian kualitatif dengan mengumpulkan data primer dari stakeholder terkait di Yogyakarta melalui wawancara mendalam untuk mengetahui lebih mendalam terkait pelaksanaan dan hambatan pemenuhan hak politik kelompok disabilitas. Dalam tulisan ini terungkap bahwa ada potensi regulasi yang berlaku di Indonesia untuk menghilangkan hak politik penyandang disabilitas, selain itu juga didapati dalam pelaksanaan teknis Pemilu masih didapati pula hambatan yang membuat kelompok disabilitas tidak bisa menunaikan hak politiknya dalam Pemilu Oleh karena diperlukan langkah komprehensif oleh pemerintah untuk menjamin hak politik kelompok disabilitas.
\end{abstract}

Kata Kunci: hak politik; penyandang disabilitas; pemilu. 


\section{PENDAHULUAN}

Indonesia pernah mengalami peristiwa penting terkait pemenuhan hak dipilih penyandang disabilitas. Pada Pemilu tahun 2004 Abdurrahman Wahid (Gus Dur) maju sebagai kandidat Presiden RI yang diusung oleh Partai Kebangkitan Bangsa (PKB). Gus Dur yang dikenal mengalami kekurangan dalam penglihatan ternyata tereleminasi dari bursa calon presiden. Saat itu Komisi Pemilihan Umum (KPU) telah membuat SK KPU No. 26 dan No. 31 tahun 2004 berkaitan dengan petunjuk teknis penilaian syarat sehat jasmani dan rohani calon presiden atau wakil presiden yang menyebutkan bahwa seorang calon presiden dan calon wakil presiden harus sehat jasmani dan rohani yang dibuktikan melalui pemeriksaan yang dilakukan oleh Ikatan Dokter Indonesia (IDI). Dalam proses seleksi diumumkan KPU bahwa pasangan Calon Presiden Gus Dur sebagai calon presiden (capres) dan Marwah sebagai calon wakil presiden (cawapres) dari PKB tidak diloloskan. KPU beralasan bahwa Gus Dur mengalami gangguan kesehatan secara fisik, meskipun hasil pemeriksaan inteligensia menunjukan bahwa Gus Dur memiliki kemampuan inteligensia yang lebih baik dibandingkan dengan capres dan cawapres yang lain. ${ }^{1}$

Keputusan KPU menggagalkan pencalonan Gus Dur merupakan bentukpenghalangan terhadap hak dipilih seorang penyandang disabilitas. Keputusan tersebut akhirnya menimbulkan aksi protes berlangsung marak. Pada umumnya mereka melihat bahwa keputusan KPU ini bertendensi politis untuk menghambat naiknya Gus Dur sebagai presiden RI serta sebagai perlakuan diskriminatif. Misi Pemantauan Pemilu Uni Eropa Glyn Ford dalam konferensi pers tentang laporan akhir pemantauan pemilu Uni Eropa di Indonesia menilai bahwa penetapan syarat kesehatan bagi capres pada Pemilu Presiden 2004 oleh Misi Pemantauan Pemilu Uni Eropa dinilai sebagai perlakuan diskriminatif. Menurut Ford, ketentuan yang menyangkut keadaan kesehatan calon seperti yang termuat dalam keputusan KPU Nomor 31 Tahun 2004 tidak lazim dalam praktik internasional. Karena itu, pendiskualifikasian

$1 \quad$ Mujar Ibnu Syarif, "Syarat Kesehatan Fisik Bagi Calon Presiden Dalam Perspektif Politik Islam Dan Politik Indonesia," AHKAM 17, no. 171-198 (2017): hlm.188, https:// media.neliti.com/media/publications/197226-ID-syaratkesehatan-fisik-bagi-calon-presid.pdf.
Gus Dur bersifat diskriminatif dan melanggar prinsip demokrasi. Pelanggaran itu terutama pada sektor kebebasan untuk memilih dan dipilih serta pelanggaran hak asasi manusia yang memiliki cacat. $^{2}$

Pada peristiwa tersebut dua hal krusial terjadi terkait hak politik penyandang disabilitas. Pertama terkait hak dipilih penyandang disabilitas yang tidak dipenuhi dikarenakan alasan yang diskriminatif yaitu karena status disabilitas yang disandangnya, kemudian kedua hak memilih penyandang disabilitas yang ingin memilih calon yang juga penyandang disabilitas. Tergambar saat itu masih ada pandangan miring terhadap penyandang disabilitas yang ingin berpatisipasi dalam pesta demokrasi, pandangan tersebut menjadi ancaman tersendiri terhadap hak politik penyandang disabilitas yaitu terkait hak memilih dan dipilih.

Didalam negara yang menganut sistem demokrasi Pemilihan Umum (Pemilu) merupakan salah satu sendi untuk tegaknya sistem politik demokrasi yang bertujuan untuk mengimplementasikan prinsip-prinsip demokrasi dengan cara memilih wakil rakyat yang duduk di lembaga perwakilan atau permusyawaratan rakyat, membentuk pemerintahan, melanjutkan perjuangan mengisi kemerdekaan, dan mempertahankan keutuhan Negara Kesatuan Republik Indonesia (NKRI) dengan mengikut sertakan rakyat dalam kehidupan ketatanegaraan sebagaimana dimaksud oleh Pancasila dan Undang-Undang Dasar Negara Republik Indonesia 1945 (UUD NKRI 1945).

Hak Pilih warga negara baik memilih maupun hak dipilih dalam Pemilu merupakan salah satu substansi penting dalam perkembangan demokrasi dan sekaligus sebagai bukti adanya eksistensi dan kedaulatan yang dimiliki rakyat dalam pemerintahan. Dengan demikian, hak pilih adalah hak warga negara untuk memilih wakil dan dipilih sebagai wakil di lembaga perwakilan rakyat melalui pemilu yang demokratis.

Hak warga negara untuk ikut berpartisipasi dalam pemilu disebut sebagai hak pilih, yang terdiri dari hak pilih aktif (hak memilih) dan hak

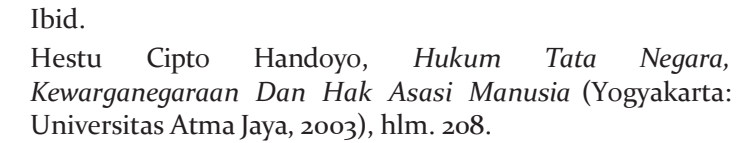


pilih pasif (hak dipilih) ${ }^{4}$. Hak memilih adalah hak warga negara untuk memilih wakilnya di dalam suatu pemilihan umum. Keikutsertaan warga negara dalam pemilu merupakan serangkaian kegiatan membuat keputusan, yaitu apakah memilih atau tidak memilih dalam pemilu. Sedangkan hak dipilih (hak pilih pasif) adalah hak warga negara untuk dipilih menjadi anggota suatu Badan Permusyawaratan/Perwakilan Rakyat dalam suatu pemilu.

Hak memilih dan hak dipilih merupakan hak yang dilindungi dan diakui keberadaannya dalam Konstitusi Negara Republik Indonesia (UndangUndang Dasar Negara Republik Indonesia Tahun 1945). Adapun ketentuan yang mengatur adalah Pasal 27 Ayat (1), Pasal 28D Ayat (3), Pasal 28E Ayat (3). Hal tersebut juga diatur di dalam Pasal 43 Ayat (1) Undang-Undang Nomor 39 Tahun 1999 Tentang Hak Asasi Manusia. Ketentuan-ketentuan tersebut menjadi dasar hukum bagi setiap warga negara Indonesia untuk memiliki kebebasan untuk ikut serta menentukan wakil-wakil mereka, baik untuk duduk dalam lembaga legislatif maupun sebagai pimpinan lembaga eksekutif yang dilakukan melalui pemilu. Dengan begitu setiap warga negara yang akan menggunakan hak tersebut dalam setiap pemilu harus terbebas dari segala hal yang dapat menimbulkan rasa takut dan segala bentuk diskrimininasi untuk menyalurkan haknya dalam memilih dan dipilih dalam setiap proses pemilu. Hal tersebut dapat dimaknai bahwa hak dipilih sebagai bagian dari hak pilih merupakan Hak Asasi Manusia (HAM) yang dapat diimplementasikan dalam pemilihan umum yang demokratis.

Setiap warga negara berhak terlibat aktif dalam kehidupan berpolitik. Hak ini terkandung dalam berbagai ketentuan hukum baik yang bersifat internasional maupun nasional. Penyandang disabilitas, sebagai bagian dari warga negara Indonesia juga berhak terlibat aktif dalam kehidupan politik sesuai dalam Pasal 21 Deklarasi Universal Hak Asasi Manusia, Pasal 25 Kovenan Hak Sipol, Pasal 28D ayat (3), Pasal 28HAyat 2 dan Pasal 28I Ayat (2) UUD 1945 setelah amandemen dan Pasal 43 Ayat (1) dan (2) UU No. 39/1999 Tentang Hak Asasi Manusia menegaskan setiap warga negara berhak mendapatkan kesempatan

4 C.ST. Kansil, Hukum Tata Pemerintahan Indonesia (Jakarta: Ghalia Indonesia, 1985), hlm. 2-5. yang sama dalam pemerintahan, baik untuk dipilih maupun memilih tanpa diskriminasi. ${ }^{5}$

Berdasarkan rangkaian peraturan perundangundangan nasional terkait hak politik, tidak ada satu pun ketentuan yang bersifat diskriminatif. Oleh karena itu dalam konteks ini hak penyandang disabilitas untuk memilih maupun dipilih harus dijamin dan diikut sertakan secara aktif dalam setiap momentum dalam konteks ini adalah pemilu. Dalam hal hak memilih penyandang disabilitas wajib mendapatkan akses yang bersahabat dengan mereka, perangkat pemilu serta petugas yang memahami kebutuhankebutuhan khusus penyandang disabilitas. Dalam hal hak dipilih penyandang disabilitas wajib diberikan kesempatan dalam berpartisipasi dalam setiap kegiatan pemilu, memiliki akses yang sama dengan yang lain untuk mengikuti kontestasi pemilu melalui jalur-jalur yang telah disediakan oleh peraturan perundang-undangan yang berlaku.

Selain ketentuan tersebut hak penyandang disabilitas juga diperkuat dengan konvensi PBB Tentang Hak-Hak Penyandang Disabilitas dan Undang-Undang Nomor 8 Tahun 2016 tentang Penyandang Disabilitas Kemudian pada Pasal 29 Konvensi PBB tentang Hak-Hak Penyandang Disabilitas diatur bahwa negara-negara anggota menjamin hak-hak politik penyandang disabilitas dan memberikan kesempatan bagi mereka menggunakan hak tersebut setara dengan anggota masyarakat lainnya, baik untuk dipilih maupun memilih. Berkaitan dengan Pemilu masih ada beberapa peraturan pelaksana lain yaitu UndangUndang Nomor 7 Tahun 2017 tentang Pemilu, Undang-Undang Nomor 42 Tahun 2008 tentang Pemilu Presiden dan Wapres, Undang-Undang Nomor 8 Tahun 2012 tentang Pemilu Anggota DPR, DPD dan DPRD, Peraturan KPU Nomor 3 Tahun 2009 tentang Pedoman Teknis Pelaksanaan Pemungutan dan Penghitungan Suara di Tempat Pemungutan Suara dalam Pemilihan Umum Anggota DPR, DPD, DPR Provinsi dan Kabupaten/Kota, Peraturan KPU Nomor 29 Tahun 2009 tentang Pedoman Teknis Pelaksanaan Pemungutan dan Penghitungan Suara Pemilu Presiden dan Wakil Presiden, Peraturan KPU Nomor 23 Tahun 2008 Tentang Pedoman Pelaksanaan Sosialisasi dan Penyampaian

\footnotetext{
$5 \quad$ Republik Indonesia, Undang-Undang No. 39 Tahun 1999 Tentang Hak Asasi Manusia, 1999.
} 
Informasi Pemilu Anggota DPR, DPD Dan DPR Provinsi dan Kabupaten/Kota.

Namun demikian peraturan-peraturan tersebut belum cukup menjamin hak penyandang disabilitas dalam berpartisipasi pada pemilu. Hak berpolitik mereka terasa masih diabaikan. Masih banyaknya hambatan pada berbagai tahapan dan mekanisme pemilu yang dirasa masih diskriminasi bagi penyandang disabilitas. Sebagai contoh pada tahapan pemilu terdapat penghambat dari tahap pemutakhiran data pemilih sampai dengan pemungutan dan penghitungan suara. Beberapa contoh misalnya, tak ada iklan layanan masyarakat untuk penyandang disabilitas, beberapa penderita disabilitas tertentu tidak didaftarkan dalam daftar pemilih, pengumuman atau sosialisasi tahapan pemilu kurang mempertimbangkan kebutuhan akses informasi penyandang tunarungu dan tunanetra. Hambatan lainnya, penyandang tuna grahita sedang dan berat banyak yang tidak ikut pemungutan suara. Dalam pelaksanaan pemilu terdapat beberapa TPS yang tidak aksesibel bagi pengguna kursi roda sehingga pemungutan suara dilakukan oleh petugas dengan cara mendatangi mereka. Penyandang tunarungu yang tidak mendengar pada saat dipanggil namanya untuk giliran mencoblos dianggap tidak ada, selain itu sistem contreng/coblos dianggap tidak konsisten pada Pemilu 2009.

Dalam tataran teknis, hambatan penyandang disabilitas saat Pemilu yang tidak mendukung pelaksanaan aspirasi penyandang disabilititas meliputi penggunaan istilah sehat jasmani dan rohani yang merugikan terutama calon legislatif penyandang disabilitas. Juga belum adanya pemahaman maupun penyelesaian atas pelanggaran akses pemilu. Selain itu terdapat beberapa peraturan perundang-undangan yang membatasi hak-hak penyandang disabilitas dalam menggunakan hak politiknya. Misalnya tidak dicantumkannya undang-undang yang mendukung prinsip non-diskriminasi pada undang-undang pemilu, serta pencantuman persyaratan sehat jasmani dan rohani merupakan terminologi merugikan yang tidak mengacu pada Undang-Undang Nomor 36 Tahun 2009 Tentang Kesehatan $^{6}$.

6 Imma Indra Dewi, "Hak Politik Disabilitas," FISIP Universitas Atmajaya Yogyakarta Bernas Jogja, last modified 2014, https://fisip.uajy.ac.id/2014/02/13/hakpolitik-penyandang-disabilitas/.
Indonesia harus menghormati, menghargai, dan menjunjung prinsip dan tujuan Piagam Perserikatan Bangsa-Bangsa serta Deklarasi Universal Hak-hak Asasi Manusia, yang selanjutnya disingkat DUHAM. DUHAM ini berisi pokok-pokok hak asasi manusia dan kebebasan dasar yang dijadikan sebagai acuan dalam penegakan dan penghormatan hak asasi manusia baik bagi anggota PBB sendiri maupun masyarakat yang berada di wilayah yurisdiksinya.

Dalam perkembangannya PBB mengesahkan Kovenan tentang Hak-hak Sipil dan Politik bersama-sama dengan Protokol Opsional pada Kovenan tentang Hak-Hak Sipil dan Politik dan Kovenan tentang Hak-Hak Ekonomi, Sosial, dan Budaya. Kovenan Internasional tentang HakHak Sipil dan Politik beserta Protokol Opsional pada Kovenan Internasional tentang Hak-Hak Sipil dan Politik mulai berlaku pada tanggal 23 Maret 1976 (Penjelasan Undang-Undang Nomor 12 Tahun 2005 tentang Pengesahan International Covenant On Civil And Political Rights (Kovenan Internasional Tentang Hak-Hak Sipil Dan Politik).

Sebagai negara hukum yang memiliki kewajiban untuk menjunjung penegakan dan penghormatan hak asasi manusia, Indonesia sudah mengambil langkah dengan meratifikasi Kovenan tentang Hak-hak Sipil dan Politik melalui Undang-undang Nomor 12 Tahun 2005 tentang Pengesahan International Covenant on Civil and Political Rights (Kovenan Internasional tentang Hak-Hak Sipil dan Politik). Hal ini disertai konsekuensi bahwa Pemerintah Indonesia memiliki tanggungjawab untuk memenuhi pelaksanaan hak sipil dan politik setiap warganegara. adalah

Hak-hak yang diatur dalam Pasal 21 Duham

1) Berhak turut serta dalam pemerintahan negaranya secara langsung atau melalui wakil-wakil yang dipilih secara bebas;

2) Berhak atas kesempatan yang sama untuk diangkat dalam jabatan pemerintahan negaranya;

3) Kemauan rakyat harus menjadi dasar kekuasaan pemerintah, dimana kehendak ini harus dinyatakan dalam pemilihan umum yang dilaksanakan secara berkala dan murni, dengan hak pilih yang bersifat umum dan setara, dengan pemungutan suara secara 
rahasia ataupun dengan prosedur lain yang menjamin kebebasan memberikan suara.

Hak-hak politik yang diatur dalam Pasal 25 Kovenan Internasional tentang Hak-Hak Sipil dan Politik adalah hak dan kesempatan tanpa pembedaan dan pembatasan yang tidak wajar, salah satu hak politik yang dijamin dalam kovenan internasional tersebut adalah hak setiap warga negara untuk ikut serta dalam penyelenggaraan urusan publik, untuk memilih dan dipilih, serta mempunyai akses berdasarkan persyaratan umum yang sama pada jabatan publik di negaranya. Undang-Undang Dasar Negara Republik Indonesia Tahun 1945 juga memuat ketentuan tentang hak pilih, yaitu hak setiap warga negara untuk memilih dan dipilih dalam rangka lembaga perwakilan rakyat.

Hak dan jaminan setiap warga negara untuk diperlakukan sama oleh negara juga diatur dalam Pasal 27 Ayat (1) UUD Negara Republik Indonesia Tahun 1945 yang menyatakan bahwa segala warga negara bersamaan kedudukannya di dalam hukum dan pemerintahan dan wajib menjunjung hukum dan Pemerintahan itu dengan tidak ada kecualinya, ketentuan tersebut dipertegas kembali dalam pasal 28 I ayat (2) bahwa setiap orang bebas dari perlakuan yang bersifat diskriminatif atas dasar apapun dan berhak mendapatkan perlindungan terhadap perlakuan yang bersifat diskriminatif itu. Di dalam konteks HAM menyatakan bahwa setiap orang memiliki kedudukan yang sama dan harus diperlakukan secara sama oleh negara sebagaimana yang diamanatkan dalam Pasal 3 Ayat (3) UndangUndang Nomor 39 Tahun 1999 tentang Hak Asasi Manusia yaitu "setiap orang berhak atas perlindungan hak asasi dan kebebasan dasar manusia, tanpa diskriminasi”.

Pasal 25 Kovenan Internasional tentang Hak-hak Sipil dan Politik Setiap warga negara harus mempunyai hak dan kesempatan, tanpa pembedaan apapun, sebagaimana yang dimaksud dalam Pasal 2 dan tanpa pembatasan yang tidak layak, untuk :

1. Ikut serta dalam urusan pemerintahan, baik secara langsung maupun melalui wakilwakil yang dipilih secara bebas;

2. Memlilih dan dipilih pada pemilihan umum berkala yang murni, dan dengan hak pilih yang universal dan sama, serta dilakukan melalui pemungutan suara secara rahasia untuk menjamin kebebasan menyatakan keinginan dari para pemilih.

3. Memperoleh akses pada pelayanan umum di negaranya atas dasar persamaan dalam arti umum. $^{7}$

Secara tegas pasal tersebut mengatur tentang hak setiap warga negara untuk ikut serta dalam penyelenggaraan urusan publik, untuk memilih dan dipilih, serta hak akses berdasarkan persyaratan umum yang sama pada jabatan publik di negaranya. Pasal tersebut memuat ketentuan tentang hak untuk memilih dan dipilih, termasuk hak memilih dalam pelaksanaan pemilihan umum. Selanjutnya pada Deklarasi Universal Hak Asasi Manusia pasal 21 Ayat (1) setiap orang berhak untuk berpartisipasi dalam pemerintahan negaranya, baik secara langsung atau melalui wakil-wakil yang dipilihnya secara bebas. ${ }^{8}$

Dalam kenyataannya penyandang disabilitas merupakan kelompok yang terpinggirkan dan termarginalkan dalam masyarakat belum semua mendapatkan kesempatan yang sama termasuk kesempatan dalam berpolitik. Dalam beberapa dekade terakhir, isu disabilitas telah menjadi salah satu yang mengemuka dalam agenda berbagai kerjasama dan forum internasional, termasuk Perserikatan Bangsa-Bangsa (PBB) guliran isu disabilitas dalam sistem PBB mendapatkan sudah mendapatkan perhatian khusus sejak tahun 1980-an melalui pengadopsian Resolusi Majelis Umum (MU) PBB No. 37/52 tanggal 3 Desember 1982. Resolusi tersebut menetapkan World Programme of Action Concerning Disabled Person (WPA) sebagai strategi global berbasis hak yang pertama di dunia untuk meningkatkan pencegahan, rehabilitasi, serta partisipasi penuh dan kesempatan yang setara bagi penyadang disabilitas. ${ }^{9}$

Selanjutnya, Resolusi MU PBB No. 48/96 tanggal 20 Desember 1993 semakin memperkuat upaya tersebut melalui pengadopsian aturan standar mengenai persamaan kesempatan bagi

7 United Nations, International Covenant on Civil and Political Rights, 1966.

8 United Nations, Universal Declaration of Human Rights, 1948.

9 PBB Komisi Ekonomi dan Sosial untuk Asia dan Pasifik, Strategi Incheon Untuk "Mewujudkan Hak" Penyandang Disabilitas Di Asia Dan Pasifik (Bangkok, 2012), https:// www.unescap.org/sites/default/files/Incheon Strategy $\% 28$ Indonesian\%29.pdf. 
penyandang disabilitas, mengakui penyandang disabilitas sebagai agen pembangunan sekaligus penerima manfaat dalam seluruh aspek pembangunan. ${ }^{10}$

Dengan diratifikasinya Konvensi HakHak Penyandang Disabilitas (Convention on the Rights Of Persons With Disabilitas/CRPD) merupakan tonggak bersejarah dan merupakan titik awal menuju kemajuan dalam meningkatkan perlindungan dan pemajuan hak-hak penyandang disabilitas, dalam konvensi ini menegaskan berbagai hak umum dan spesifikasi dari penyandang disabilitas, dan mengatur mandat dan kewajiban negara pihak dalam pemenuhan hak penyandang disabilitas diantaranya penyesuaian kebijakan nasional, perwujudan lingkungan yang disability inclusive, penyediaan reasonable accommodation dan aksesibilitas di berbagai sektor baik fisik maupun non-fisik. Pergeseran paradigma dan pendekatan dalam penanganan isu disabilitas, dari yang sebelumnya menggunakn pendekatan berbasis belas kasihan ( charity based approach) menjadi pendekatan berbasis hak (charity based approach) yang pada intinya mengubah cara pandang masyarakat termasuk para pihak pembuat kebijakan dapat berubah sejalan dengan pemenuhan kewajiban negara, merupakan salah satu yang diatur dalam konvensi ini, termasuk Indonesia yang mendelegasikan konvensi ini kedalam Undang-Undang Nomor 19 Tahun 2011 tentang Pengesahan Konvensi HakHak Penyandang Disabilitas tanggal 18 Oktober 2011.

Pemilihan umum yang berlangsung 5 (lima) tahun sekali menuntut peran aktif dari masyarakat yang berpartisipasi dan partai politik yang mengakomodir partisipasi tersebut, selain itu kewajiban partai politik memberikan pendidikan politik kepada masyarakat agar masyarakat dapat berpartisipasi serta menjadikan masyarakat tidak apatis setiap pelaksanaan agenda 5 tahunan ini karena partai politik juga merupakan sebuah wadah bagi masyarakat untuk terlibat berpartisipasi aktif dalam proses demokrasi dan pengelolaan sebuah negara, karena partai politik secara hirarki tujuannya adalah sebagai mediator antara masyarakat dan pemerintah dalam hal penyaluran aspirasi yang berlaku juga untuk penyandang disablitas sebagai warga negara indonesia yang tentunya memiliki hak yang sama dengan penduduk wilayah Indonesia yang lainnya, hampir semua wilayah di Indonesia terdapat kelompok atau penyandang disabilitas, oleh karena itu hak politik penyandang disabilitas harus diperhitungkan dan dipenuhi, baik untuk memilih maupun dipilih mengingat jumlah penyandang disabilitas yang banyak tentunya dalam ajang pemilu suara mereka sangat diperlukan serta keterlibatan merekapun (untuk dipilih) akan sangat menentukan perubahan bangsa kedepan dan lebih khususnya untuk perubahan kepada para penyandang disabilitas itu sendiri.

Berangkat dari permasalahan tersebut maka rumusan masalah dalam penelitian ini adalah bagaimana pemenuhan hak politik bagi penyandang disabilitas dalam pemilu yang berdasarkan perspektif HAM (Hak Sipil dan Politik) dan apa saja hambatan yang dialami dalam perwujudan hak politik bagi penyandang disabilitas.

\section{METODE PENELITIAN}

Penelitian ini menggunakan metode kualitatif dengan pendekatan deskriptif analisis yang akan mengungkapkan secara sistematis berbagai temuan dalam penelitian. Aktivitas pengumpulan data primer dan sekunder dapat diperoleh secara bersamaan pada saat dilapangan. Hal ini dimaksudkan untuk mengoptimalkan waktu penelitian yang terbatas. Pengumpulan data primer dilakukan dengan wawancara mendalam (indepth interview), sedangkan pengumpulan data sekunder dikumpulkan dari berbagai sumber seperti media massa, literatur dan pemberitaan di internet.

Narasumber serta informan kunci (Key Informan) dalam penelitian ini ditetapkan secara Purposive Sampling. Informan dalam pedoman wawancara ini adalah pihak penyelenggara pemilu, partai politik, komunitas disabilitas serta pendapat dari akademisi.

Teknik pengumpulan data dalam penelitian ini menggunakan dua teknik pengumpulan data yaitu penelitian lapangan (field research) dan studi kepustakaan (library studies). Data-data dalam penelitian ini bersumber pada data primer dan data sekunder. Penelitian ini dilakukan dalam rangka memperoleh data primer merupakan data empiris yang diperoleh dilapangan melalui

10 Ibid. 
wawancara mendalam. ${ }^{11}$ (Indepht Interview) dengan sejumlah informan kunci (key informan), studi pustaka, studi dokumentasi.

Wawancara (indepht interview) adalah proses memperoleh keterangan untuk tujuan penelitian dengan cara tanya jawab sambil bertatap muka antara peneliti dengan narasumber dengan menggunakan instrumen yang dinamakan interview guide. Walaupun wawancara adalah proses percakapan yang berbentuk tanya jawab dengan tatap muka, wawancara adalah suatu proses pengumpulan data untuk suatu penelitian interview guide diperlukan untuk wawancara berencana (standardized interview). ${ }^{12}$

\section{PEMBAHASAN}

\section{A. Hak Memilih dan Dipilih Menurut Hak Sipil dan Politik}

Penyandang disabilitas perlu dilibatkan dalam proses demokrasi, karena tanpa terlibatnya penyandang disabilitas menghilangkan arti demokrasi sesungguhnya. Sebuah Pemilu dapat dipertanyakan andai satu warga atau kelompok tidak dipenuhi hak politiknya. Pelibatan penyandang disabilitas tanpa diskriminasi menjamin berjalannya pemilu yang berintegritas, oleh karena itu partisipasi penyandang disabilitas sejatinya memainkan peran yang sama dalam proses Pemilu. ${ }^{13}$

Dasar dari semua hak asasi ialah bahwa manusia harus memperoleh kesempatan untuk berkembang sesuai dengan bakat dan cita-citanya. Setelah dunia mengalami perang yang melibatkan hampir seluruh dunia dimana hak asasi diinjakinjak, timbul keinginan untuk merumuskan hakhak asasi manusia itu dalam suatu naskah internasional usaha ini pada tahun 1948 berhasil dengan diterimanya Universal Declaration of

$11 \quad$ Hal yang dimaksud wawancara adalah proses memperoleh keterangan untuk tujuan penelitian dengan cara tanya jawab sambil bertatap muka antara peneliti dengan narasumber dan responden dengan menggunakan alat yang dinamakan Interview guide. Walaupun wawancara adalah proses percakapan yang berbentuk tanya jawab dengan tatap muka, wawancara adalah proses pengumpulan data untuk suatu penelitian Nazir, Metode Penelitian (Jakarta: Ghalia Indonesia, 2003), hlm.234.

12 Kontjaraningrat, Metode Wawancara" Dalam Kontjaraningrat (Ed) Metode Penelitian Masyarakat (Jakarta: Gramedia, 1986), hlm.58-72.

13 Tony Yuri Rahmanto, "Hak Pilih Penyandang Disabilitas Mental Ditinjau Dari Perspektif Hak Asasi Manusia," Jurnal HAM 10, no. 1 (2019): 32.
Human Rights pernyataan sedunia tentang Hakhak Asasi Manusia oleh negara-negara yang tergabung dalam perserikatan bangsa-bangsa. ${ }^{14}$

Sejak lahirnya Negara Kesatuan Republik Indonesia tahun 1945 bangsa Indonesia telah menjunjung tinggi HAM, sikap tersebut terdapat didalam Pancasila dan UUD Tahun 1945, dimana termuat tentang ketentuan negara tentang penghormatan HAM warga negara, sehingga dalam praktek penyelanggaraan negara, perlindungan dan penjaminan terhadap HAM dan hak-hak warga negara (citizen's rights) atau hak-hak konstitusional warga negara (the citizen's constitusional rights) dapat terlaksana. Hak memberikan suara atau memilih (rights to vote) merupakan hak dasar (basic rights) setiap individu atau warga negara yang harus dijamin pemenuhannya oleh negara. Hak dipilih dengan Hak Asasi Manusia bagaikan "dua sisi mata uang" penggunaan hak pilih, termasuk hak untuk dipilih (Hak pilih pasif) merupakan suatu hak dan sekaligus bagian dari hak asasi manusia, hak ini dimilikinya bukan karena diberikan oleh masyarakat atau berdasarkan hukum positif, melainkan berdasarkan martabatnya sebagai manusia. ${ }^{15}$

Pada hakikatnya setiap warga negara tanpa ada pengecualian memiliki hak dan kewajiban kepada negara berhak untuk berperan aktif dalam pemerintahan termasuk hak berpolitik mencakup hak untuk memilih bahkan hak untuk dipilih karena sudah terjamin didalam Undang-Undang Dasar 1945 mulai pasal 27 ayat (1) dan (2), pasal $28 \mathrm{D}$ ayat (3), pasal $28 \mathrm{E}$ ayat $(3)^{16}$ Sangat jelas didalam pasal-pasal tersebut diatas bahwa sangat tidak dibenarkannya adanya pengabaian akan hak-hak bagi semua warga negara baik golongan apapun ras, agama bahkan bagi penyandang disabilitas sekalipun memiliki hak dan kewajiban yang sama, ketentuan-ketentuan didalam undangundang diatas diatur dalam peraturan perundangundangan dibawahnya.

\footnotetext{
14 Tenang Haryanto and Johannes Sudaryana, "Pengaturan Tentang Ham Berdasarkan Undang-Undang 1945 Sebelum Dan Sesudah Amandemen.," Jurnal Dinamika Hukum 8, no. 2 (2008): hlm.1.

15 Rhona KM Smith, Hukum Hak Asasi Manusia (Yogyakarta: PUSHAM UII, 2008), hlm.11.

16 Republik Indonesia, Undang Undang Dasar Negara Republik Indonesia 1945, 1945.
} 
Perlindungan dan pengakuan hak-hak warga negara terdapat didalam undang-undang HAM dimana hak tersebut meliputi : a) hak untuk hidup; b) hak berkeluarga dan melanjutkan keturunan; c) hak mengembangkan diri; d) hak memperoleh keadilan; e) hak atas kebebasan pribadi; f) hak atas rasa aman; g) hak atas kesejahteraan; h) hak turut serta dalam pemerintahan; i) hak wanita; dan j) hak anak, serta pada point (h) secara nyata negara memberikan pengakuan kepada warga negara untuk ikut serta dalam pemerintahan terutama dalam hak untuk dipilih. Pada bagian kedelapan hak turut serta dalam pemerintahan tepatnya pada pasal 43 ayat (1) setiap warga negara berhak untuk dipilih dan memilih dalam pemilihan umum berdasarkan persamaan hak melalui pemungutan suara yang langsung, umum, bebas, rahasia, jujur dan adil sesuai dengan ketentuan peraturan perundang-undangan, (2) setiap warga negara berhak turut serta dalam pemerintahan dengan langsung dipilihnya dengan bebas, menurut cara yang telah ditentukan dalam peraturan perundangundangan, (3) setiap warga negara dapat diangkat dalam jabatan pemerintahan. Hak turut serta dalam pemerintahan dapat dikatakan sebagai pengejawantahan dari demokrasi, sehingga jika hak ini tidak ada dalam satu negara maka negara tersebut tidak semestinya mengakui diri sebagai negara demokratis, karena negara yang menganut demokrasi pada umumnya mengakomodir hak politik warga negaranya dalam suatu penyelenggaraan pemilihan umum baik bersifat langsung maupun tidak langsung, mengingat Indonesia menganut azas demokrasi sehingga sudah sebuah keharusan bagi negara sebagai pemberi hak kepada penikmat hak tersebut.

Negara Indonesia mengakui dan melindungi hak setiap warga negaranya untuk mengambil bagian dalam pelaksanaan urusan publik, hak memilih dan dipilih, serta hak atas akses terhadap pelayanan publik sebagaimana tertuang dalam pasal 25 Undang-Undang 12 Tahun 2005 tentang pengesahan International Covenant on Civil And Political Rights (Kovenan Internasional tentang Hak-Hak Sipil dan Politik), konvenan ini mengukuhkan pokok-pokok HAM di bidang sipil dan politik yang terdapat dalam Declaration of Human Rights (Deklarasi Universal Hak Asasi Manusia). Negara-negara yang telah meratifikasi ICCPR, memiliki sejumlah kewajiban. Pertama, negara harus bertanggung jawab melakukan penghormatan, perlindungan, dan pemenuhan atas semua hak ICCPR. Pelaksanaan penghormatan, perlindungan dan pemenuhan dilakukan tanpa diskriminasi dalam bentuk apapun.

"Setiap negara pihak kepada konvenan ini berjanji untuk menghormati dan menjamin hak-hak yang diakui dalam konvenan ini bagi seтиa orang yang berada di dalam wilayahnya dan tunduk pada wilayah hukumnya, tanpa pembedaan apapun seperti ras, warna kulit, jenis kelamin, bahasa, agama, politik atau pendapat lain, usul-usul kebangsaan atau sosial, kekayaan, kelahiran atau status lainnya'( ICCPR Pasal 2 ayat 1)

Kedua, kewajiban negara-negara pihak untuk melakukan tindakan yang diperlukan untuk menjamin terjadinya perlindungan dan pemenuhan hak, bila suatu negara (pihak) dalam yurudiksinya belum menjamin hak-hak yang ada dalam ICCPR
"Apabila belum diatur dalam ketentuan perundang-undangan atau kebijakan lainnya yang ada, setiap negara pihak dalam konvenan ini berjanji untuk mengambil langkah-langkah yang diperlukan sesuai dengan proses konstitusinya dan dengan ketentuan-ketentuan dalam konvenan ini, untuk menetapkan perundang-undangan atau kebijakan lain yang diperlukan untuk memberlakukan hak-hak yang diakui dalam konvenan ini" (ICCPR Pasal 2 ayat 2)

Ketiga, negara berkewajiban melakukan langkah-lankah pemulihan yang efektif (effective remedies) kepada korban yang telah dilanggar hak-haknya, negara harus menyediakan sistem pemulihan yang efektif untuk memastikan terpenuhinya hak-hak korban. Indonesia sebagai salah satu negara pihak ICCPR sendiri sudah seharusnya mengimplementasikan dan patuh terhadap aturan yang tercantum dalam ICCPR hukum terkait di Indonesia belaku pada 28 Oktober 2005 ICCPR adalah perjanjian internasional yang menetapkan kewajiban mengikat secara hukum pada negara-negara pihak untuk menghormati HAM yang diatur dalam DUHAM, dalam konteks hak pilih dan dipilih sebagai hak politik dalam Deklarasi Universal Hak-Hak Asasi Manusia 
secara tegas diuraikan dalam pasal $21^{17}$ sebagai berikut :

Table 1 Hak Politik Dalam Kerangka DUHAM

\begin{tabular}{|l|l|}
\hline $\begin{array}{l}\text { Pada } \\
\text { ayat 1 }\end{array}$ & $: \begin{array}{l}\text { Setiap orang berhak turut serta dalam } \\
\text { pemerintahan negerinya sendiri, baik } \\
\text { dengan langsung maupun dengan } \\
\text { perantaraan wakil-wakil yang dipih } \\
\text { dengan bebas }\end{array}$ \\
\hline $\begin{array}{l}\text { Pada } \\
\text { ayat 2 }\end{array}$ & $\begin{array}{l}\text { Setiap orang berhak atas kesempatan } \\
\text { yang sama untuk diangkat dalam jabatan } \\
\text { pemerintahan negerinya }\end{array}$ \\
\hline $\begin{array}{l}\text { Pada } \\
\text { ayat 3 }\end{array}$ & $\begin{array}{l}\text { Kemauan rakyat harus menajdi dasar } \\
\text { kekuasaan pemerintah; kemauan ini } \\
\text { harus dinyatakan dalam pemilihan- } \\
\text { pemilihan berkala yang jujur dan yang } \\
\text { dilakukan menurut hak pilih yang bersifat } \\
\text { umum dan berkesamaan, serta dengan } \\
\text { pemungutan suara yang rahasia ataupun } \\
\text { menurut cara-cara yang menjamin } \\
\text { kebebasan mengeluarkan suara }\end{array}$ \\
\hline
\end{tabular}

Dari pasal diatas dapat dimaknai bahwa setiap orang memiliki hak dan kedudukan yang sama dalam pemerintahan yang dilakukan melalui proses pemilu yang demokrasi yang tidak bersifat diskriminatif setiap orang (warga negara) memiliki hak dan kesempatan yang sama. Dengan mencermati pasal-pasal hak politik, hak memilih dan dipilih, baik dalam konstitusi Indonesia maupun kesepakatan yang disepakati bersama melalui konvenan internasional yang di tuangkan ke dalam peraturan yang mengikat di Indonesia menunjukan suasana eforia terhadap nilai kebebasan, kesetaraan, keadilan dan kesejahteraan yang menjadi nilai dasar kemanusiaan, sekaligus sebagai HAM yang baru diraih oleh bangsa Indonesia, namun demikian suasana tersebut tidak serta merta menjamin kebebasan dan kesetaraan masih terdapat pembatasan didalam berpartisipasi secara penuh bagi para penyandang disabilitas didalam berpartisipasi didalam politik.

Partisipasi politik merupakan kondisi menyangkut hak asasi warga negara dibidang politik, tak terkecuali kalangan penyandang disabilitas, hanya saja keikutsertaan penyandang disabilitas dalam berpartisipasi masih menghadapi kendala meski secara normatif jaminan hak mereka telah dilindungi berbagai instrumen hukum internasional seperti CRPD (Konvensi hak-hak penyandang disabilitas) sebagai salah satu negara yang ikut meratifikasi CRPD tentunya Indonesia memiliki komitmen memberikan kemudahan bagi kalangan difabel, termasuk jaminan hak berpartisipasi dalam politik. Walaupun secara konstitusional hak-hak tersebut telah dijamin, namun disisi lain masih terdapat dalam peraturan perundang-undangan yang mengakibatkan kerugian tidak terpenuhinya/terabaikan, adanya pelanggaran/ berlaku diskriminatif. Persyaratan tersebut jelas sangat diskriminatif bagi kalangan penyandang disabilitas berpartisipasi didalam politik sehingga tidak terakomodasinya hak dipilih penyandang disabilitas terutama dengan adanya persyaratan didalam Undang-Undang Nomor 8 Tahun 2012 Pasal 51 pada huruf (f) pasal tersebut menyaratkan bakal calon anggota DPR, DPRD baik Provinsi Maupun Kabupaten/ Kota selain warga Indonesia menyaratkan bahwa untuk menjadi calon tersebut harus sehat secara jasmani dan rohani, terlihat dari kesempatan hak untuk dipilih dalam jabatan-jabatan politik yang mensyaratkan sehat jasmani dan rohani, dan disabilitas dianggap tidak memenuhi syarat tersebut. Muncul keragu-raguan bagi penyandang disabilitas jika ingin mencalonkan diri dengan adanya persyaratan tersebut karena tidak memiliki ukuran yang jelas mengenai sehat jasmani dan rohani yang dimaksud dalam pasal tersebut, selain itu masih ada pemahaman dimasyarakat bahwa penyandang disabilitas termasuk didalam persyaratan itu sehingga penyandang disabilitas tidak bisa mencalonkan diri, akibat multitafsir baik dikalangan disabilitas sendiri maupun dari cara pandang masyarakat bahkan partai politik dan penyelenggara pemilu, sehingga diperlukan penjabaran yang lebih luas agar tidak menimbulkan perdebatan di dalam persyaratan pencalonan bagi semua pihak terkhusus bagi disabilitas, dan harus dipahami secara luas didalam manafsirkannya penyandang disabilitas yang terlihat lemah secara fisik namun secara rohani tidak mengalami kendala, dan negara harus berperan penuh didalam memenuhinya memberikan ruang seluasluasnya kepada penyandang disabilitas dalam berpartisipasi didalam berpolitik bukan hanya sebagai pemilih namun melainkan menempatkan mereka sebagai orang yang terpilih kedepannya sehingga sebuah kewajiban bersama untuk mempelopori karena hanya mereka para disabiltas yang tahu dan memahami kebutuhannya sendiri. 
Selain dengan diperjelasnya bunyi pasal didalam proses pencalonan untuk menjadi anggota DPR, DPD, DPRD solusi yang lain yang ditawarkan didalam mengakomodir para penyandang disabilitas berpartisipasi didalam politik berkaca pada keterwakilan perempuan yang hak politiknya bisa diakomodir berdasarkan kouta, karena salama ini perempuan mengalami diskriminasi sehingga demokrasi menjaminnya dengan memberikan dalam bentuk kouta 30 persen didalam pencalonan dimana hukumnya wajib untuk memasukan perempuan di dalam daftar calon pencalegan, dengan banyaknya perempuan yang bisa masuk di lembaga pemerintahan maka banyak melahirkan kebijakan yang berpihak kepada perempuan, jadi wajar jika kaum yang mengalami diskriminasi perlu mendapat afirmasi dalam berpartisipasi didalam politik melalui keterlibatannya didalam pengambil kebijakan didalam pemerintahan sehingga dengan keterlibatan didalamnya maka diharapkan dapat menghilangkan kebijakan yang bersifat diskriminasi, bisa masuknya perempuan di dalam lembaga pemerintahan dengan sistem kouta tersebut yang berangkat dari ketidaksetaraan dan diskriminasi yang ada selama ini, para penyandang disabilitas memiliki persamaan dimana selama ini belum secara sepenuhnya menikmati kebebasan, belum bisa menikmati hak-haknya selaku individu yang dilindungi oleh konstitusi maka sudah sepatutnya perlakuan yang ada terhadap perempuan didalam pemenuhan hak berpolitiknya bisa diterapkan pula untuk para penyandang disabilitas melalui sistem kouta dan regulasi memberikan ruang bagi penyandang disabilitas untuk bisa dipilih walau masih sebatas tataran pencalonan namum minimal negara telah memberikan ruang kepada para penyandang disabilitas, apakah nanti mereka bisa terpilih atau tidak akan kembali kepada rakyat yang memilih dan partai politik mengakomodasinya para penyandang disabilitas salah satu calon legislator yang mereka dukung.

Selain solusi diatas selain dengan memperjelas isi dari pasal tentang pencalonan baik sebagai anggota DPR, DPRD, Anggota DPD untuk mendorong keterwakilan penyandang disabilitas, tindakan affirmative action berupa diskon untuk mendapatkan kursi melalui jumlah perolehan suara untuk penyandang disabilitas mendapatkan pengurangan sebanyak 25 persen untuk dapat duduk di lembaga legislatif baik di tingkat pusat maupun daerah, dan untuk calon perseorangan atau DPD syarat pengumpulan Kartu Tanda Penduduk sebagai dukungan maka untuk penyandang disabilitas cukup dengan setengah dari ketentuan yang diberlakukan, pola pola demikian sebagai bentuk sebuah tindakan nyata dan berkeadilan bagi penyandang disabilitas dalam memperjuangkan dan memenuhkan hak disabilitas di keterwakilan lembaga legislatif bukan tanpa alasan hal ini dikemukakan, namun mengingat negara belum mampu untuk menyediakan fasilitas untuk penyandang disabilitas dalam bersosialisasi (berkampanye) lokasi kampanye bagi penyandang disabilitas belum tentu ramah kepada disabilias itu sendiri akses jangkauannya, selain itu bagi calon disabilitas dalam hal ini penyandang disabilitas tunarunggu masih melakukan kampanye seperti yang calon non disabilitas apakah ada jaminan dari negara dalam hal ini pihak penyelenggara Pemilu menyediakan fasilitas untuk dia berkampanye atau ada metode kampanye lain yang bisa disiapkan kedepannya agar program visi dan misi nya tersampaikan kepada pemilih, sejauh ini belum bisa disiapkan dan belum ada jaminan maka wajar tindakan affirmative action ini dilaksanakan.

Terkait kategori/jenis disabilitas yang bisa menduduki lembaga lembaga legislatif apa kah harus ada kualifikasi khusus responden menyampaikan hal initidak perlu mengingat semua harus diberikan ruang melainkan yang harus lebih dipersoalkan adalah fasilitas yang negara berikan, dan kesalahan terbesar adalah mencoba membuat kebijakan bagi penyandang disabilitas namun membuat kategori dan indikator yang dibuat oleh mereka yang non disabilitas, sehingga jangan dipaksa terutama bagi penyandang disabilitas (mental retardasi) dituntut bisa berbicara seperti orang yang menonjol atau vokal di parlemen melainkan dia harus didudukan agar dia berbicara sesuai dengan kapasitasnya dalam menyampaikan sesuatu, mengingat tidak bisa berbicara inklusif dengan setengah-setengah, berbicara hak asasi manusia, berbicara kesetaraan hak namun masih membeda-bedakan, dan responden menekankan yang lebih utama untuk dibangun adalah fasilitas yang aksesibilitas, inklusifitas dan secara prinsip pembatasan tidak bisa dilakukan dengan cara mengamputasi dari hak itu sendiri walaupun didalam hak untuk dipilih bisa dibatasi semisal narapidana yang ancaman pidananya diatas 5 
tahun tidak berhak untuk dipilih itu merupakan proses dari pembatasan. Namun sebagai sebuah konsep disabilitas jenis apapun berhak, masalah dia akan terpilih atau tidak itu biarkan publik yang akan menentukannya dalam hal ini minimal pemerintah memberikan ruang kepada mereka untuk berbicara atas kepentingan mereka sendiri, disisi lain pencantuman persyaratan baik sehat jasmani dan rohani dan cakap berbicara, membaca dan menulis menurut responden dalam klasula sendiri sudah diskriminatif, dan tolak ukur indikator yang menyatakan penyandang disabilitas merupakan orang yang tidak sehat masih kurang jelas dasarnya. ${ }^{18}$

Keterlibatan penyandang disabilitas akan membuka jalan kebijakan pemerintah secara inklusif yang lebih luas. Jika penyandang disabilitas menunjukkan jumlah dan kepentingan mereka pada kotak suara, politisi kemungkinan akan lebih cenderung mengembangkan kebijakan yang menarik bagi kelompok ini seperti pendidikan, pekerjaan, transportasi dan pelayanan kesehatan yang inklusif. Penyandang disabilitas yang berpartisipasi di kehidupan politik juga memiliki kesempatan memengaruhi kebijakan berentang luas dan membuka peluang untuk memasukkan konsep progresif legal mengenai disabilitas ke dalam legislasi nasional ke tingkatan yang lebih tinggi. ${ }^{19}$

\section{B. Pemenuhan Hak Memilih dan Dipilih Penyandang Disabilitas Dalam Pemilu di Provinsi Daerah Istimewa Yogyakarta}

Penyelenggara dalam pemenuhan hak memilih KPUD DIY dalam pelaksanaan tugasnya dalam Pemilu telah melakukan upaya pemenuhan hak-hak seluruh warga negara tanpa terkecuali penyandang disabilitas. Upaya tersebut tergambar dalam data yang didapatkan bahwa KPUD DIY melakukan pendataan penyandang disabilitas untuk masuk dalam Daftar Pemilih Tetap (DPT).

18 Hasil Wawancara Eko Riyadi, Direktur Pusat Studi Hak Asasi Manusia Universitas Islam Indonesia, 2017, n.d.

19 Rahmanto, "Hak Pilih Penyandang Disabilitas Mental Ditinjau Dari Perspektif Hak Asasi Manusia," 32.
Table 2.2 Daftar Pemilih Tetap Penyandang Disabilitas Provinsi DIY

\begin{tabular}{|c|c|c|c|c|}
\hline No & Daerah & $\begin{array}{l}\text { DPT } \\
\text { Penyandang } \\
\text { Disabilitas }\end{array}$ & $\begin{array}{l}\text { Jumlah } \\
\text { Disabilitas } \\
\text { yang } \\
\text { menggunakan } \\
\text { Hak Pilih } \\
\text { (orang) }\end{array}$ & Persentase \\
\hline 1 & Bantul & 3.115 & 495 & $15,89 \%$ \\
\hline 2 & $\begin{array}{l}\text { Gunung } \\
\text { Kidul }\end{array}$ & 2.479 & 485 & $19,56 \%$ \\
\hline 3 & Sleman & 4.184 & 327 & $7,8 \%$ \\
\hline 4 & $\begin{array}{l}\text { Kulon } \\
\text { Progo }\end{array}$ & 774 & 547 & $70 \%$ \\
\hline 5 & $\begin{array}{l}\text { Kota } \\
\text { Yogyakarta }\end{array}$ & 494 & 350 & $70 \%$ \\
\hline
\end{tabular}

Tabel diatas dapat menggambarkan bahwa dengan banyaknya penyandang disabilitas yang telah masuk didalam Daftar Pemilih Tetap (DPT) namun masih banyak juga penyandang disabilitas yang tidak menunaikan hak pilihnya walaupun tingkat partisipasi secara umum meningkat pada salah satu kabupaten yang ada di Daerah Istimewa Yogyakarta.Untuk Kabupaten Bantul, Kabupaten Sleman dan Gunung Kidul pihak KPU tetap mendalami lebih lanjut kenapa jumlah partisipasi penyandang disabilitas sangat rendah, berbeda dengan yang terjadi di Kota Yogyakarta dan Kulonprogo sudah menunjukan jumlah partisipasi penyandang disabilitas sudah cukup baik walaupun masih kisaran $70 \%$, tentu banyak factor yang menyebabkan rendahnya tingkat partisipasi penyandang disabilitas menurut anggota KPU DI. Yogyakarta tetapi Political will, tekad semua pihak serta hasrat semua pihak agar dapat merawat dan meningkatkan hak pilih, berangkat dari kejadian kasus di Kabupaten Bantul ketika pihak KPU telah berusaha seoptimal mungkin melaksanakan sosialisasi ke dalam panti dan kerjasama yang baik pihak panti menyiapkan lokasi tempat pelaksanaan sosialisasi namun kenyataannya pada saat pelaksanaan hari pencoblosan tidak satupun penghuni panti melaksanakan hak pilihnya dikarenakan alasan tidak adanya petugas panti yang mendampingi, sehingga perlu kerjasama yang baik antara KPU dengan pihak lain agar kejadian serupa tidak akan terulang kembali. Pada kesempatan yang sama responden berbangga berkat kerjasama jajaran Komisi Pemilihan Umum Daerah Istimewa Yogyakarta pernah mendapatkan penghargaan terkait dengan pemberian akses kepada penyadang 
disabilitas (Pemilu Akses) dan mendapatkan juara 1 (satu) tingkat nasional.

Pada pelaksanaan pemilihan anggota legislatif Komisi Pemilihan Umum Daerah Istimewa Yogyakarta menyiapkan alat bantu untuk penyandang Tuna Netra yaitu pada daftar calon dibuatkan buku daftar calon sehingga teman-teman disabilitas Netra bisa melihat sendiri calonnya, walaupun tidak adanya post anggaran untuk pencetakan tersebut, terkecuali untuk calon Dewan Perwakilan Daerah (DPD) dan berdasarkan pendapat para anggota komisioner Komisi Pemilihan Umum Daerah Istimewa Yogyakarta maka memutuskan setiap tempat pemungutan suara (TPS) wajib tersedia 1 buku daftar calon baik untuk calon anggota Legislatif maupun untuk anggota Dewan Perwakilan Daerah, walaupun dianggap menyalahi penggunaan anggaran dikarenakan anggaran yang tersedia hanya untuk alat praga sosialisasi misalnya plano/poster namun anggaran tersebut dialihkan peruntukannya untuk template sehingga menjadi sebuah dilema bagi komisioner KPU DIY, dan atas keputusan bersama maka pihak KPU DIY berkoordinasi dengan KPU Pusat menyikapi hal ini, namun pihak KPU Pusat tidak memberikan jawaban terhadap hal ini karena berbenturan dengan regulasi anggaran, namun disisi lain komisioner KPU Pusat tetap berpandangan digunakan sebagai alat sosialisasi berupa template bagi penyandang disabilitas, namun dikuatirkan akan menjadi sebuah temuan bagi Badan Pemeriksa Keuangan (BPK), sebuah terobosan yang patut di contoh dari para Komisioner Komisi Pemilihan Umum Daerah Yogyakarta ini tetap melaksanakan pembuatan template bagi penyandang disabilitas netra walaupun nanti kedepannya dianggap menyalahai dari penggunaan anggarannya namun atas dasar keputusan bersama dan demi kepentingan partisipasi bagi panyandang disabilitas maka proses ini tetap dilanjutkan, berdasarkan hasil investigasi dari Badan Pemeriksa Keuangan menggangap ini bukan sebagai kesalahan. Berkat kerja keras dan keputusan yang diambil secara bersama Komisi Pemilihan Umum Daerah Istimewa Yogyakarta mendapatkan apresiasi secara nasional, KPUD DIY menjadi sorotan karena telah mampu berinovasi dalam hal itu, sehingga sekarang secara nasional anggaran untuk template telah dialokasikan.
Terkait pemenuhan hak dipilih penyandang disabilitas, jalur pemenuhan adalah melalui partai politik. Partai politik sebagai salah satu pilar demokrasi di Indonesia mempunyai fungsi salah satunya adalah rekrutmen politik. Menurut Miriam Budiardjo, fungsi partai politik diantaranya adalah sarana komunikasi politik, sosialisasi politik (political socialization), sarana rekrutmen politik, dan pengatur politik. Sementara berdasarkan Undang-Undang Nomor 2 Tahun 2008 tentang Partai Politik, disebutkan fungsi-fungsi partai politik dalam Pasal 11 ayat (1) diantaranya adalah sebagai rekrutmen politik dalam proses pengisian jabatan politik melalui mekanisme demokrasi dengan memperhatikan kesetaraan dan keadilan gender. Partai politik sebagai representasi dari aspirasi masyarakat telah diberikan hak dalam pengajuan calon dalam kontestasi Pemilu. Partai politik juga merupakan institusi yang sah dan legitimate untuk mengajukan kontestan dalam pemilu. Oleh karenanya, tanggung jawab partai politik untuk menyediakan kader untuk mengisi jabatan publik tanpa diskriminasi seharusnya menjadi agenda utama dalam kegiatan partai. ${ }^{20}$

Menurut keterangan responden Anggota DPRD Kota Yogyakarta dari Fraksi Partai Keadilan Sejahtera, bukan sebuah kewajiban penyandang disabilitas untuk duduk di badan pemerintahan (Legislatif), melainkan bisa diwakilkan dari non disabilitas masalah pokok yang terpenting adalah pengambil kebijakan tersebut adalah orang-orang yang peduli dan mengerti kepada penyandang disabilitas, pertimbangannya setelah penyandang disabilitas nanti terpilih dan duduk di legislatif tidak adanya jaminan bahwa yang bersangkutan akan memperjuangkan hak-hak penyandang disabilitas selain itu proses politik di legislatif sangat sulit untuk membuat logika-logika politik yang bisa di terima dan mempengaruhi anggota lainnya karena keterbatasan yang dimiliki oleh penyandang disabilitas sehingga dirasa sangat sulit memperjuangkan kepentingan disabilitas.

Sejauh ini tidak terdapat kendala atau masalah dalam mengakomodir penyandang disabilitas untuk masuk ke dalam dunia politik, sebaliknya partai politik harus pintar melihat peluang khusus bagi penyandang disabilitas yang berkualitas mengingat jumlah yang sangat

20 Tony Yuri Rahmanto, "Calon Tunggal Dalam Perspektif Hak Memilih Dan Dipilih Di Provinsi Banten," Jurnal HAM 9, no. 2 (2018): 115 . 
signifikan, kualifikasi khusus diperlukan dalam perekrutan penyandang disabilitas untuk menjadi anggota partai atau dalam tahap pencalonan tidak semua jenis disabilitas bisa mendapatkannya khususnya bagi penyandang disabilitas mental karena memilih itu berdasarkan akal yang dimiliki merdeka, selain itu ditakutkan pilihan tersebut disalahgunakan oleh orang lain yang memiliki kepentingan. Didalam kefraksian sebuah keputusan diambil berdasarkan suara-suara anggota yang ada didalam fraksi sehingga tidak diperlukan kualifikasi khusus bagi penyandang disabilitas, selain itu karena suara di legislatif secara kolektifitas dan tidak semua anggota legislatif penyandang disabilitas sehingga bisa saling mendukung.

Terkait dengan pencantuman "Mampu secara jasmani dan rohani", "dapat berbicara, membaca dan atau menulis dalam bahasa Indonesia pada pencalonan anggota legislatif diperlukan aturan khusus, mengingat jika dilakukan revisi UndangUndang pemilihan umum anggota DPR, DPD dan DPRD memakan waktu yang panjang sehingga akan lebih sederhana di buat didalam aturan Komisi Pemilihan Umum dalam menyikapinya hak peyandang disabilitas. ${ }^{21}$

DPD Partai PDI Perjuangan Provinsi DIY sesuai dengan Anggaran Dasar dan Anggaran Rumah Tangga tidak ada pembedaan atas dasar apapun terkait terkait dengan hak dipilih dan partai dengan platform partai orang kecil tidak akan membedakan atas dasar apapun baik pria maupun wanita, warna rambut, suku dan agama, tingkat ekonomi dan tingkat social begitu pula dengan penyandang disabilitas yang terpenting bagi PDI Perjuangan adalah warga negara Indonesia, dan lebih di utamakan komitmennya terhadap ideologi partai dan jati diri partai serta budayabudaya partai, menurut responden itu merupakan hal yang utama untuk menjaring calon kader yang akan masuk kedalam PDI Perjuangan yang berideologikan Pancasila, dan Negara Kesatuan Republik Indonesia serta Undang-Undang Dasar Negara Republik Indonesia atas dasar tersebut sehingga tidak membedakan bagi siapapun yang akan bergabung dengan PDI Perjuangan termasuk penyandang disabilitas

21 Hasil Wawancara Dwi Budi Utomo Anggota DPRD Kota Yogyakarta Komisi D, Responden Merupakan Kader Partai Keadilan Sejahtera, 2017.
DPD PDIP menyadari bahwa jumlah penyandang disabilitas terutama di Yogyakarta yaitu berkisar sampai $11 \%$, sangat disayangkan dari pemerintah tidak menyediakan fasilitas di dalam proses demokrasi karena terbentur oleh anggaran dari pihak KPUD, padahal dengan jumlah yang banyak dan komunitas-komunitas penyandang disabilitas cukup banyak sangat disayangkan jika Negara dalam hal ini pemerintah daerah tidak bisa memfasilitasi kepentingan disabilitas dalam berdemokrasi, keprihatinan kita sebagai bangsa yang hidup secara bersama-sama, Dewan Pimpinan Daerah PDI Perjuangan Yogyakarta berusaha semaksimal mungkin agar dapat memfasilitasi dengan baik apapun keadaannya mengingat potensi potensi yang dimiliki oleh penyandang disabilitas setempat penyandang disabilitas tidak meminta untuk dikasihani walaupun dengan keadaan yang dimilikinya melainkan kita patut mencontoh semangat yang tinggi dari para penyandang disabilitas, semua orang memiliki tantangan sendiri-sendiri baik disabilitas maupun non disabilitas namun utuk penyandang disabilitas mereka harus terfasilitasi oleh pemerintah agar bisa bekerja dan berkarya dengan layak, bisa bersekolah dengan baik, bisa bersosial dengan baik termasuk juga memberikan kesempatan untuk berpolitik dalam hak memilih dan dipilih.

Menurut responden untuk memperbaiki dan membawa kearah maju para penyandang disabilitas sudah sepatutnya disabilitas juga wajib untuk duduk di legislatif mewakili kepentingan para penyandang disabilitas lainnya, dan secara hukum nasional tidak ada batasan namun untuk Daerah Istimewa Yogyakarta untuk $50 \%$ saja tidak ada padahal potensi serta jumlah penyandang disabilitas cukup banyak, akibat kasus bencana alam gempa bumi dan kasus gunung merapi sehingga menurut responden seharusnya bisa lebih dari $11 \%$ jumlah pemilih disabilitas.

Responden berpendapat agar dapat mengakomodir semua lapisan dan menghindari sistem tarung bebas hendaknya dapat mencotoh pada pola perekrutan calon anggota legislatif seperti dahulu dimana kelompok-kelompok yang diangkat berdasarkan keterwakilan seperti keterwakilan atau suku terpencil tertentu dan tidak menutup kemungkinan dari penyadang disabilitas dapat menempatkan wakilnya sehingga dengan system dan pola seperti ini akan lebih memproteksi semua kepentingan dan semua lapisan 
Jika sekarang anggota Legislatif di Pusat sebanyak 560 maka dapat menempatkan wakilwakil dari semua golongan minimal 60 berdasarkan minoritas-minoritas sehingga orangorang dari suku pedalaman jambi, suku badui, suku tengger dan bahkan penyandang disabilitaspun bisa masuk

Sampai saat ini terdapat kader Partai Demokrasi Indonesia Perjuangan Daerah Istimewa Yogyakarta dari kalangan disabilitas mengingat dulu pernah terjadi bencana gempa sehingga banyak masyarakat yang menjadi korban bahkan menjadi disabilitas dan sebagian dari mereka masuk dalam jabatan struktural partai, dan saat ini partai PDI Perjuangan masih sangat sulit mendata penyandang disabilitas mengingat pihak keluarga yang masih malu-malu jika ada anggota keluarganya penyandang disabilitas, selain itu kesulitan dalam menemukan keberadaan mereka, tingkat pendidikan serta keahlian yang mereka miliki. Dalam proses rekrutmen anggota partai PDI Perjuangan tidak mengenal batasan begitupula dengan jenis disabilitas yang akan masuk menjadi anggota partai namun yang terpenting memiliki akal budi dan semangat yang tinggi apapun jenis disabilitas yang dialaminya pada prinsipnya tuhan memberikan sesuatu bukan untuk menghukum penyandang disabilitas melainkan untuk memberikan motivasi dan tuhan membekali itu kepada penyandang disabilitas. Sejauh ini PDI Perjuangan Yogyakarta tidak ada pembicaraan dalam hal membatasi kepentingan disabilitas dalam proses demokrasi komitmen dalam melaksanakan tugas dengan baik yang lebih dikedepankan sehingga untuk menjadi anggota legislatif untuk penyandang disabilitas tidak memiliki masalah dan negara harus memfasilitasi bukan memanjakan namun memberikan selayaknya kepada penyandang disabilitas.

\section{Hambatan Penyandang Disabilitas Dalam Pemilu di Provinsi Daerah Istimewa Yogyakarta}

Informasi, Upaya yang dilakukan KPU dalam menjamin pemenuhan hak untuk dipilih selama ini belum tersampaikan kepada para penyandang disabilitas, selama ini pihak penyelenggara masih dalam tataran memberikan sosialisasi kepada para penyandang disabilitas dalam hal untuk memilih, tata cara pemilihan TPS ramah terhadap disabilitas, pihak penyelenggara belum sepenuhnya melakukan sosialisasi hak untuk dipilih bagi penyandang disabilitas, dari beberapa responden di Yogyakarta mengaku dalam hal ini sosialisasi yang dilakukan pihak penyelenggara masih kurang dalam hal mensosialisasikan hak dipilih penyandang disabilitas baru sebatas kewajiban untuk memilih. Hambatan yang muncul dari pihak KPU adalah kesulitan menyampaikan materi sosialisasi kepada penyandang disabilitas, mengingat adanya kebutuhan khusus yang harus diperhatikan, selain itu tingkat partisipasi pemilih dikalangan disabilitas masih rendah untuk kedua daerah ini banyak penyandang disabilitas yang masuk didalam DPT namun pada saat pelaksanaan pemungutan suara masih banyak penyandang disabilitas yang tidak melakukan pemungutan suara. Dalam hal untuk meningkatkan partisipasi didalam Pemilu bagi penyandang disabilitas pihak penyelenggara tidak bisa bekerja sendiri di butuhkan kerjasama semua pihak baik keluarga dari penyandang disabilitas itu sendiri maupun stakeholder lainnya.

Aksesibilitas, Selain dari aturan regulasi yang masih menjadi multitafsir baik dikalangan penyandang disabilitas, penyelenggara pemilu bahkan partai politik tidak sedikit dari penyandang disabilitas kedepan merasa kesusahan dalam melaksanakan sosialisasi (kampanye) tempat-tempat melaksanakan kampaye tidak dibedakannya antara penyandang disabilitas dan non disabilitas tidak semua penyandang disabilitas dapat mengakses lokasi-lokasi kampanye, selain itu hambatan bagi si calon dari penyandang disabilitas dari tunawicara, tidak tersedianya fasilitas untuk kampanye bagi para penyandang disabilitas. ${ }^{22}$ Persoalan fasilitas layanan publik terutama pelayanan akses masih sangat jauh dari harapan penyandang disabilitas, sebuah permasalahan yang belum bisa diselesaikan. Perlu dilengkapi berbagai kelengkapan yang ramah difabel seperti ramp kursi roda peron, jalur kusus tunanetra, dan petunjuk arah. ${ }^{23}$

SDM Penyandang Disabilitas selain hambatan-hambatan yang tertuang diatas perlu rasanya penulis sampaikan dari beberapa

\footnotetext{
22 Hasil Wawancara Farid Bambang Siswantoro, Ketua Divisi Sumber Daya Manusia Partisipasi Masyarakat Dan Humas Komisi Pemilihan Umum Daerah Istimewa Yogyakarta, 2017.

23 Marwandianto, "Pelayanan Transportasi Publik Yang Mudah Diakses Oleh Penyandang Disabilitas Dalam Perspektif HAM," Jurnal HAM 9, no. 2 (2018): 177.
} 
responden yang mengutarakan hambatan yang dihadapai dari penyandang disabilitas itu sendiri, tidak semuanya penyandang disabilitas mempunyai mental yang kuat belum sepenuhnya penyandang disabilitas memiliki rasa percaya diri yang tinggi dalam mengikuti pertarungan politik tersebut, baik dari tingkat pendidikan yang minim dan kekuatan finansial yang cukup. Jangan sampai kedepan setelah regulasi, pemerintah khususnya pihak penyelenggara pemilu serta partai politik membuka kesempatan dalam hak untuk dipilih ditakutkan kedepan sebaliknya dari penyandang disabilitas belum memiliki kesiapan dalam mengikutinya. Berangkat dari penuturan salah satu responden dimana dengan penuh keyakinan memberikan yang baik kepada pemerintah maupun perusahaan agar dalam proses perekrutan karyawan baru harus melibatkan penyandang disabilitas didalamnya sesuai dengan perintah undang-undang penyandang disabilitas yang mewajibkan perusahaan untuk memberikan alokasi 1 persen untuk karyawan swasta dan 2 persen untuk pegawai pemerintahan, namun setelah kesepakatan dicapai dengan dibuka lowongan untuk disabilitas dalam jumlah yang besar, kenyataannya tidak ada dari penyandang disabilitas yang mengikutinya, setelah ditelusuri banyak dari penyandang disabilitas itu sendiri belum percaya diri selain tingkat pendidikan yang tidak sesuai dengan kebutuhan pekerjaan. Dari kasus yang demikian menjadi sebuah pelajaran bahwa penyandang disabilitas tidak hanya sebatas menuntut hak semata namun lebih mempersiapkan diri dengan potensi-potensi yang dimiliki sehingga kedepan berkaca pada kasus tersebut diharapakan pemerintah harus memberikan pendidikan politik kepada para penyandang disabilitas dan menanamkan rasa percaya diri dalam berpartisipasi didalam politik bukan karena kelemahan yang yang menjadi keuntungan melaikan hadirnya mereka karena potensi yang mereka miliki.

Lingkungan, Keluarga mempunyai posisi penting dalam mengedukasi dan mendukung penyandang disabilitas dalam berpartisipasi di dalam pemilu. Hal ini dikarenakan kedekatan personal keluarga dan penyandang disabilitas dalam berbagai aktivitas. Selain itu teman maupun tetangga juga mempunyai andil dalam memberikan stimulus positif bagi para penyandang disabilitas untuk mengerti hak serta kewajibannya sebagai warga negara.

Berdasarkan temuan lapangan dan juga keterangan yang diperoleh dari organisasi disabilitas bahwasanya ada beberapa keluarga yang memang dengan sengaja tidak memberikan kesempatan bagi anggota keluarganya yang menyandang disabilitas karena alasan psikologis atau aib bagi keluarga tersebut, keterbatasan fisik bukanlah menjadi penghalang bagi penyandang disabilitas untuk memperoleh hak yang sama dengan masyarakat pada umumnya. Hal ini tentu saja berlawanan ketentuan Pasal 29 UndangUndang Nomor 19 Tahun 2011 tentang Konvensi Hak-Hak Penyandang Disabilitas sebagaimana telah diratifikasi oleh Indonesia. ${ }^{24}$

\section{KESIMPULAN}

Berdasarkan uraian pada bagian terdahulu, dapat disimpulkan bahwa konsep perlindungan pemenuhan hak politik diatur dalam mekanisme ketatanegaraan Indonesia bermuara dari Pembukaan Undang-Undang Dasar Negara Republik Indonesia Tahun 1945. Konsep perlindungan hak memilih dan dipilih sebagai bagian dari hak asasi manusia merupakan constitutional rights karena diatur dalam Pasal 27 ayat (1), ayat, Pasal 28D ayat (3) Pasal 28E ayat (3), dan diatur juga dalam Undang-undang HAM Nomor 39 tahun 1999, Pasal 43 ayat (1) Kovenan Internasional Hak Sipil dan Politik Pasal $28 \mathrm{H}$ ayat 2 dan Pasal 28 I ayat (2). Pasal 5 Undang-Undang Nomor 7 Tahun 2017 Tentang Pemilihan Umum. Dengan demikian, mekanisme perlindungan hukum dapat dilakukan dengan mengajukan uji materiil (judicial review) bila ada peraturan perundangan-undangan merugikan hak-hak konstitusional warga negara. Pemenuhan hak memilih dan dipilih di Provinsi DIY sudah dilakukan oleh KPUD DIY dengan memberi fasilitas kepada pemilih penyandang disabilitas, selain itu juga KPUD DIY juga aktif melakukan pendataan penyandang disabilitas untuk masuk ke dalam Daftar Pemilih Tetap (DPT). Partai politik di Provinsi DIY juga membuka selebarlebarnya pintu kepada seluruh kalangan termasuk penyandang disabilitas tanpa terkecuali untuk berpartisipasi dalam aktifitas politik, baik dalam internal partai maupun untuk menjadi kontestan

24 Hasil Wawancara Ibnu Sukoco Divisi Advokasi CIQAL (Center for Improving Qualified Activity in Live of People with Disabilities), 2017. 
dalam Pemilu. Bahkan kedepannya partai politik di Provinsi DIY akan lebih mendorong penyandang disabilitas untuk berpatisipasi lebih aktif karena bisa menjadi nilai tambah pada partai politik dan membentuk citra partai yang lebih baik, diterima lebih luas oleh masyarakat.

Potensi hambatan dalam pemenuhan hak memilih dan dipilih ditemukan pada kerangka regulasi. Masih ada potensi aturan yang bagi para penyandang disabilitas masih multitafsir dalam berpartisipasi didalam pemilu khususnya dalam hak untuk dipilih, persepsi tentang hak politik penyandang disabilitas walaupun telah tertuang dalam undang-undang secara legal formal telah terwujud dengan baik, namun tidak menjelaskan secara detail syarat-syarat tersebut, walaupun menjelasakan bahwa cacat tubuh tidak termasuk didalam kategori gangguan kesehatan. Dalam penjelasan klausula tersebut hanya menyatakan penyandang disabilitas tubuh yang tidak termasuk kategori gangguan kesehatan, memunculkan persepsi yang berbeda, dan ditakutkan persepsi ini terbangun di masyarakat, partai politik serta penyelenggara pemilu yang kemudian mempersepsikan salah sehingga bisa menghambat hak politik terutama hak untuk dipilih bagi penyandang disabilitas.

Hambatan pada tataran implementasi di Provinsi DIY secara garis besar ada beberapa faktor antara lain Informasi, Aksesibilitas, SDM Penyandang Disabilitas, dan Lingkungan. Faktorfaktor tersebut menjadi hambatan bagi penyandang disabilitas dalam mengakses hak-hak politik dalam pemilu. Terkait affirmative action secara konsep tidak diperlukan, namun dilihat dari realita politik sekarang ini, dan pemahaman masyarakat yang masih memisahkan disabilitas dan non disabilitas, normal dan tidak normal sehingga kebijakan afirmative actions sejauh ini diperlukan dalam mengakomodir penyandang disabilitas untuk berperan aktif didalam Pemilu terutama dalam hak untuk dipilih. Kebijakan affirmative action terhadap perempuan didasarkan karena banyaknya kaum perempuan yang termarginalkan sehingga muncullah kebijakan untuk melibatkan peran aktif dari perempuan dan kesetaraan antara perempuan dan laki-laki. Sehingga dimungkinkan affirmative action untuk penyandang disabilitas baik dalam bentuk kouta maupun pengurangan jumlah perolehan suara.

\section{SARAN}

Berdasarkan uraian terdahulu dan kesimpulan di atas, disarankan hal-hal sebagai berikut. Hendaknya dengan mulai berlakunya Undang-Undang Penyandang disabilitas UndangUndang No 8 Tahun 2016, merupakan sebuah rujukan terhadap pembentukan peraturan perundang-undangan lainya yang lebih bernuansa keberpihakan dalam pemenuhan hak penyandang disabilitas terutama terkait dengan hak dipilih, segera direvisi didalam mencantumkan atau mensyaratkan ketentuan sebagaimana terdapat pada Undang-Undang Nomor 7 Tahun 2017 Tentang Pemilihan Umum pada Pasal 240 ayat 1 huruf (d) dan (h), Undang-undang Nomor 10 tahun 2016 Pasal 7 ayat 2 huruf (F), UndangUndang Nomor 8 Tahun 2012 Pasal 51 persyaratan untuk menjadi anggota legislatif (menyantumkan syarat sehat jasmani dan rohani dan) direvisi, atau lebih diperjelas lagi secara detail, sehingga tidak menjadi menjadi multitafsir terhadap para penyandang disabilitas untuk mengikuti proses tersebut, karena pada intinya hanya perbedaan dari seseorang dalam beraktivitas dan bergerak (cara berjalan dan cara berbicara, dan cara melihat), namun bukan berarti sebuah halangan untuk berpartisipasi didalam pengambilan kebijakan terutama kebijakan yang berkaitan dengan penyandang disabilitas, negara lebih memfasilitasi sarana dan prasarana serta memberikan ruang yang sebebas-bebasnya dalam mewujudkan partisipasi terutama berpartisipasi didalam politik agar tidak bertentangan dengan Undang-Undang Dasar Negara Republik Indonesia.

Perlu adanya sosialisasi kepada masyarakat khususnya keluarga dari penyandang disabilitas dapat memfasilitasi anggota keluarganya yang memiliki penyandang disabilitas agar bisa berpartisipasi dalam pemilihan umum baik nasional maupun daerah karena ini merupakan hak konstitusional yang dimilikinya serta tanamkan semangat untuk mempersiapkan potensi yang dia miliki supaya kedepan mereka bukan hanya memilih calon - calon yang mereka angap mampu, melainkan merekalah yang mencalonkan diri karena kemampuan mereka bukan karena keterbatasannya. 


\section{UCAPAN TERIMA KASIH}

Salam hormat dan ucapan terima kasih kami haturkan kepada Kepala Badan Penelitian dan Pengembangan Hukum dan Hak Asasi Manusia, Kepala Pusat Penelitian dan Pengembangan Hukum, Kepala Pusat Penelitian dan Pengembangan Hak Asasi Manusia, dan rekan-rekan peneliti yang telah mendukung kami dalam proses penulisan. Kepada seluruh jajaran pengurus Jurnal HAM Balitbangkumham dan Pusbangdatin yang telah memfasilitasi publikasi tulisan kami, kami ucapkan banyak terima kasih.

\section{DAFTAR PUSTAKA}

Brownli, Ian. Dokumen-Dokumen Mengenai Hak Asasi Manusia. jakarta: Universitas Indonesia, 1993.

Dewi, Imma Indra. "Hak Politik Disabilitas." FISIP Universitas Atmajaya Yogyakarta Bernas Jogja. Last modified 2014. https:// fisip.uajy.ac.id/2014/02/13/hak-politikpenyandang-disabilitas/.

Handoyo, Hestu Cipto. Hukum Tata Negara, Kewarganegaraan Dan Hak Asasi Manusia. Yogyakarta: Universitas Atma Jaya, 2003.

Haryanto, Tenang, and Johannes Sudaryana. "Pengaturan Tentang Ham Berdasarkan Undang-Undang 1945 Sebelum Dan Sesudah Amandemen." Jurnal Dinamika Hukum 8, no. 2 (2008).

Kansil, C.ST. Hukum Tata Pemerintahan Indonesia. Jakarta: Ghalia Indonesia, 1985.

Kontjaraningrat. Metode Wawancara" Dalam Kontjaraningrat (Ed) Metode Penelitian Masyarakat. Jakarta: Gramedia, 1986.

Marwandianto. "Pelayanan Transportasi Publik Yang Mudah Diakses Oleh Penyandang Disabilitas Dalam Perspektif HAM.” Jurnal HAM 9, no. 2 (2018): 175-189.

Nations, United. International Covenant on Civil and Political Rights, 1966.

Universal Declaration of Human Rights, 1948.

Nazir. Metode Penelitian. Jakarta: Ghalia Indonesia, 2003.
PBB Komisi Ekonomi dan Sosial untuk Asia dan Pasifik. Strategi Incheon Untuk "Mewujudkan Hak" Penyandang Disabilitas Di Asia Dan Pasifik. Bangkok, 2012. https:// www.unescap.org/sites/default/files/Incheon Strategy \%28Indonesian\%29.pdf.

Rahmanto, Tony Yuri. "Calon Tunggal Dalam Perspektif Hak Memilih Dan Dipilih Di Provinsi Banten." Jurnal HAM 9, no. 2 (2018): 103-119.

- "Hak Pilih Penyandang Disabilitas Mental Ditinjau Dari Perspektif Hak Asasi Manusia." Jurnal HAM 10, no. 1 (2019): 19-38.

Republik Indonesia. Undang-Undang No. 39 Tahun 1999 Tentang Hak Asasi Manusia, 1999.

_. Undang Undang Dasar Negara Republik Indonesia 1945, 1945.

Smith, Rhona KM. Hukum Hak Asasi Manusia. Yogyakarta: PUSHAM UII, 2008.

Syarif, Mujar Ibnu. "Syarat Kesehatan Fisik Bagi Calon Presiden Dalam Perspektif Politik Islam Dan Politik Indonesia." AHKAM 17, no. 171-198 (2017). https://media.neliti. com/media/publications/197226-ID-syaratkesehatan-fisik-bagi-calon-presid.pdf.

Hasil Wawancara Dwi Budi Utomo Anggota DPRD Kota Yogyakarta Komisi D, Responden Merupakan Kader Partai Keadilan Sejahtera, 2017.

Hasil Wawancara Eko Riyadi, Direktur Pusat Studi Hak Asasi Manusia Universitas Islam Indonesia, 2017, n.d.

Hasil Wawancara Farid Bambang Siswantoro, Ketua Divisi Sumber Daya Manusia Partisipasi Masyarakat Dan Humas Komisi Pemilihan Umum Daerah Istimewa Yogyakarta, 2017.

Hasil Wawancara Ibnu Sukoco Divisi Advokasi CIQAL (Center for Improving Qualified Activity in Live of People with Disabilities), 2017. 
